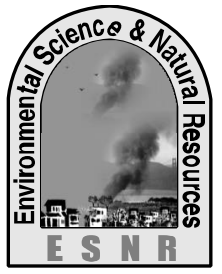

\title{
Change of Vegetation Cover at Rohingya Refugee Occupied Areas in Cox's Bazar District of Bangladesh: Evidence from Remotely Sensed Data
}

\author{
M. Rahman, M. S. Islam* and T. A. Chowdhury
}

Department of Geography and Environment, Shahjalal University of Science and Technology, Sylhet-3114, Bangladesh

*Corresponding author: mdsaiful91@gmail.com

\begin{abstract}
Nearly one million Rohingya Refugees are living in Coxôs Bazarð a south-eastern district of Bangladesh; among them, more than half a million have fled Myanmar since August 2017. There are always some impacts of refugee settlements on the host environment. Hence, this study has made an initiative to investigate the changes of vegetation covers in four refugee occupied Unions of Teknaf and Ukhia Upazila. Analysing the remotely sensed Landsat imageries using Normalized Difference Vegetation Index method, the spatial extent of sparse vegetation, moderate vegetation, and dense vegetation before and after the occurrence of 2017 Influx have been quantified. The result reveals that nearly 21,000 acres of dense vegetation and more than 1700 acres of moderate vegetation have been reduced within the period of one year in-between 2017 and 2018. On the other hand, during the same period, the refugee sites have been expanded by almost 6000 acres. The main reasons for this drastic reduction of vegetation include the construction of refugee camps by felling the forest and consumption of firewood by refugees from the surrounding forest of their camps. Arrangement of alternative cooking fuel, relocation of refugees, reforestation, and accelerating the repatriation process may reduce the further degradation of vegetation.
\end{abstract}

Keywords: Bangladesh-Myanmar crisis, Deforestation, NDVI, Rohingya refugee, Vegetation covers

\section{Introduction}

A refugee is generally a person who is outside their country of nationality or habitual residence and cannot return safely owing to serious and indiscriminate threats to life resulting from generalized violent events like war, forceful expulsion, genocide, etc. (UNHCR, 2011). The world is now witnessing the highest level of displacement on record (UNHCR, 2018). An unprecedented 68.5 million people around the world has been forced to leave home (UNHCR, 2018a; UNHCR, 2018b). Almost one million of them are Rohingya Muslims who are currently taking refuge in Coxôs Bazar of Bangladesh (ISCG, 2018).

The Rohingya is a Muslim minority ethnicity residing in Rakhine State (then Arakan) of Myanmar for centuries and facing discrimination and repression under successive Burmese governments for decades (Leider, 2018). Effectively denied citizenship under the 1982 Citizenship Law, they are one of the largest stateless populations in the world (MSF, 2002). Since late August 2017, more than 671,000 Rohingya Muslims have entered Bangladesh to escape the Myanmar militaryôs large-scale crackdown (HRW, 2017). Before the most recent influx of 2017, several inflows were occurred previously and more than quarter million of them were already living in Bangladesh for decades (HRW, 2017).
Impact of refugee crisis on the environment and natural resource of the host country has become an emerging issue in the present world as temporary shelters are often built near environmentally sensitive areas, viz. national parks, sanctuary, reserve forests or agriculturally marginal areas (Martin, 2015; Shepherd, 1995) and itôs causing some environmental degradation like deforestation and firewood depletion, land degradation, unstable ground water extraction, water pollution, etc. (Gomez et al. 2010). Some previous studies have found different types of environmental degradation in different places on earth, e.g. vegetation and land degradation in Sudan (Gomez et al. 2010), forest depletion in Western Kenya (Braun et al. 2016), agricultural land degradation in Syria (Muller et al. 2016), occurred due to the refugee crisis. In case of Bangladesh, a few studies have been carried out recently intending the assessment of environmental degradation (focusing on vegetation) in Coxôs Bazar due to refugee accommodation. Hasan et al. (2018) found that due to this massive influx in 2017 a substantial expansion (1355 ha) of refugee settlement has occurred mostly replacing the forested land, degrading the vegetation cover surrounding the camps by 2283 ha. Imtiaz (2018) has also reported a drastic change of vegetation cover has occurred in late 2017 in Teknaf Upazila and Teknaf Wildlife Sanctuary (TWS) by decreasing of 1284 ha and 103 ha respectively. The 
main gap of these studies is both of them have analysed the data up to December 2017, while the influx and expansion of refugee sites were continued until April 2018. Therefore, these studies represent only a partial scenario of the first few months of the 2017 Influx. Moreover, Imtiaz (2018) has only considered Teknaf Upazila and have not studied Ukhiya Upazila, which is also hosting a large number of refugees. Although the influx has stopped now and the expansion of camps is also stopped subsequently, but the refugees are still exploiting forest resources by collecting fire woods and settlement materials. That is why a further study is needed to assess the changes in vegetation cover during this whole period of the influx. The present study aims to fill that gap of literature by assessing the changes of vegetation cover in four refugee occupied Unions, i.e. Palong Khali, Whykong, Nhilla, and Baharcchara of Ukhiya and Teknaf Upazila during the period of 2017-Refugee-Influx.

\section{Materials and Methods}

\section{Study area}

This study was conducted in four Unions (lowest unit in the administrative hierarchy in Bangladesh) of Teknaf and Ukhia Upazila in Coxôs Bazar District. Both of Teknaf and Ukhia Upazila are covered by a significant area of tropical evergreen and semi evergreen forest and other vegetation (Rahman, 2016). The Unions have been selected based on the presence of refugee settlements. They are: Palong Khali in Ukhia Upazila and Whykong, Nhilla, Baharchhara in Teknaf Upazila. Figure 1 shows the map of selected Unions and refugee sites. There are about 100 refugee camps across the study area in three major refugee sites known as Kutupalong-Balukhali Site in Palong Khali, Unchiprang site in Whykong, and NayaparaLeda site in Nhilla Union. There is another newly established refugee site named Shamlapur in Baharchhara Union.

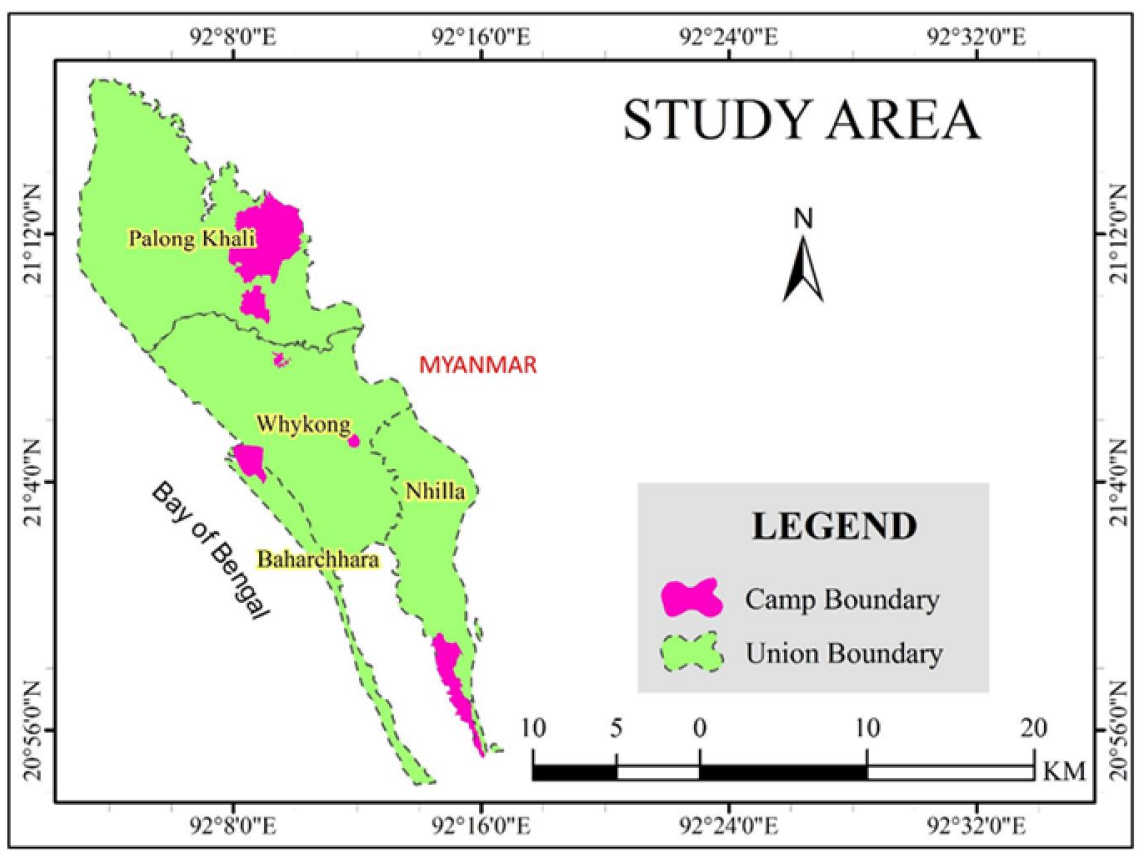

Fig. 1. Selected Unions of Teknaf and Ukhia Upazila.

\section{Data}

The study is mainly based on primary data extracted from multi-temporal satellite data, i.e. Landsat images of particular sensor (TM, OLI \& TIRS) captured in the year of 1988, 1998, 2008, 2017, and 2018. Among them, 2017 data was acquired before the beginning of refugee influx and 2018 data was acquired in April 2018 when the influx was almost stopped. Although the main objective of this study is to detect the change of vegetation cover in-between the period of August 2017 and April 2018, the data of previous decades have also been collected to show a comparison between the recent change and historical change. Particulars of the satellite imageries are shown in Table 1. 
Table 1. Particulars of satellite imageries

\begin{tabular}{lcccccc}
\hline Upazila & Satellite ID & Sensor ID & Path/Row & $\begin{array}{c}\text { Acquisition } \\
\text { Date }\end{array}$ & $\begin{array}{c}\text { Spatial } \\
\text { Resolution }\end{array}$ & Image Quality \\
\hline Ukhiya & Landsat 5 & TM & $136 / 45$ & $1988-02-12$ & $30 \mathrm{~m}$ & 9 \\
Ukhiya & Landsat 5 & TM & $136 / 45$ & $1998-12-08$ & $30 \mathrm{~m}$ & 9 \\
Ukhiya & Landsat 5 & TM & $136 / 45$ & $2008-11-01$ & $30 \mathrm{~m}$ & 9 \\
Ukhiya & Landsat 8 & OLI \& TIRS & $136 / 45$ & $2017-05-02$ & $30 \mathrm{~m}$ & 9 \\
Ukhiya & Landsat 8 & OLI \& TIRS & $136 / 45$ & $2018-04-03$ & $30 \mathrm{~m}$ & 9 \\
Teknaf & Landsat 5 & TM & $135 / 46$ & $1988-02-21$ & $30 \mathrm{~m}$ & 9 \\
Teknaf & Landsat 5 & TM & $135 / 46$ & $1998-12-17$ & $30 \mathrm{~m}$ & 9 \\
Teknaf & Landsat 5 & TM & $135 / 46$ & $2008-11-10$ & $30 \mathrm{~m}$ & 9 \\
Teknaf & Landsat 8 & OLI \& TIRS & $135 / 46$ & $2017-05-11$ & $30 \mathrm{~m}$ & 9 \\
Teknaf & Landsat 8 & OLI \& TIRS & $135 / 46$ & $2018-04-12$ & $30 \mathrm{~m}$ & 9 \\
\hline
\end{tabular}

\section{Image processing and classification}

To detect different types of vegetation covers, Normalized Difference Vegetation Index (NDVI) method has been used. ERDAS Imagine 2014 and ArcGIS 10.2 were used for image processing, including radiometric and atmospheric correction, NDVI calculation and classification, and map generation to achieve the objectives of the study. The NDVI values were calculated using following formula:

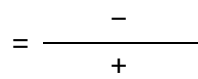

Here, NIR = Near-infrared; and Red = Red spectral bands of the image. The value of NDVI ranges between -1 and +1 . Total four types of land cover have been detected based on the values of NDVI, viz. Oे.1 (Non-vegetation), >0.1 to Oे.3 (Sparse Vegetation),
$>0.3$ to Oे.5 (Moderate Vegetation), and $>0.5$ to Ò (Dense Vegetation) (Weier and Hoque 2000; Nath 2015). Finally, the area of each type of vegetation covers of each Union in different years has been calculated by measuring pixel count.

\section{Accuracy assessment}

The classification accuracy assessment was conducted with the reference of the raw satellite images. The entire process was executed by comparing the reference images (Table 2) with the classified images with some random points following stratified random sampling procedure. The detail results of the accuracy assessment are shown in Table 3. The result reveals that the value of overall classification accuracy varies from $79.22 \%$ to $90.79 \%$ and Kappa statistics varies from 0.76 to 0.87 that indicates high accuracy.

Table 2. Details of reference data used for accuracy assessment

\begin{tabular}{ccccc}
\hline Year & Reference Data & Spatial Resolution & Date & Source \\
\hline 1988 & Landsat TM 5 True Composite & 30 meter & $12 / 02 / 1988$ & earthexplorer.usgs.gov \\
1998 & Landsat TM 5 True Composite & 30 meter & $08 / 12 / 1998$ & earthexplorer.usgs.gov \\
2008 & IKONOS & 4 meter & $31 / 12 / 2008$ & Google Earth \\
2017 & PlanetScope Scene & 3 meter & $26 / 05 / 2017$ & www.planet.com \\
2018 & PlanetScope Scene & 3 meter & $13 / 04 / 2018$ & www.planet.com \\
\hline
\end{tabular}

Table 3. Detail outcomes of accuracy assessment

\begin{tabular}{ccc}
\hline Year & Overall Classification Accuracy & Overall Kappa Statistics \\
\hline 1988 & $83.12 \%$ & 0.7689 \\
1998 & $84.42 \%$ & 0.7708 \\
2008 & $88.31 \%$ & 0.8077 \\
2017 & $89.61 \%$ & 0.8479 \\
2018 & $90.79 \%$ & 0.8757 \\
\hline
\end{tabular}




\section{Results}

The NDVI value greater than 0.1 represents vegetation. To delineate the vegetation cover more clearly, the whole vegetation cover is classified into three classes: sparse vegetation, moderate vegetation, and dense vegetation. Table 4 presents the area of each vegetation cover in the year of 1988, 1998, 2008, 2017, and 2018 , while Figure 2 shows the graphical presentation of the vegetation covers and their change. The percentage change of each type of vegetation have been calculated considering two time spans, viz. from 1988 to 2017 and from 2017 to 2018 . The results reveal that dense vegetation, which represents the actual forest cover, has been increased noticeably from the year of 1988 to 2008 in all Unions. In-between the year of 2008 and 2017 , this type of vegetation has decreased slightly. In 2018, the area of dense vegetation in three Unions named Palong Khali, Whykong, and Nhilla indicates that a substantial amount of forest cover has decreased in comparison with the previous year of 2017. Only
Baharchhara Union shows a slight increment of dense vegetation cover in 2018 than 2017. The largest amount of reduction of forest cover after 2017Refugee-Influx has occurred in Palong Khali as nearly four-fifth portion of dense vegetation have been reduced. More than half of the dense vegetation has been lost in Nhilla Union followed by Whykong Union which has lost almost one-third of its forest after the latest refugee inflow.

In case of moderate vegetation, all of the Unions show irregular characteristics in-between the year of 1988 and 2018. In 2017, moderate vegetation in Palong Khali and Whykong shows a decreasing amount of more than half of their initial extent in 1988 followed by Nhilla which shows a quarter amount of decreasing. But interestingly, their extent in Palong Khali has increased by almost nine-tenth portion in 2018 than that of the previous year, while the rest of the three Unions indicate decreasing of the moderate vegetation cover.

Table 4. Area of different vegetation covers and their changes

\begin{tabular}{|c|c|c|c|c|c|c|c|}
\hline \multirow{2}{*}{ Vegetation Cover Class } & \multicolumn{5}{|c|}{ Area (Acre) } & \multirow{2}{*}{$\begin{array}{c}\text { \% Change } \\
(1988-2017)\end{array}$} & \multirow{2}{*}{$\begin{array}{c}\text { \% Change } \\
(2017-2018)\end{array}$} \\
\hline & 1988 & 1998 & 2008 & 2017 & 2018 & & \\
\hline \multicolumn{8}{|l|}{ Palong Khali Union } \\
\hline Sparse Vegetation & 5679 & 3384 & 578 & 3684 & 10234 & -35.13 & +177.80 \\
\hline Moderate Vegetation & 12296 & 16773 & 9906 & 6121 & 11544 & -50.22 & +88.60 \\
\hline Dense Vegetation & 13977 & 12547 & 22541 & 18986 & 3990 & +35.84 & -78.98 \\
\hline \multicolumn{8}{|l|}{ Whykong Union } \\
\hline Sparse Vegetation & 5353 & 3176 & 722 & 2578 & 7724 & -51.84 & +199.61 \\
\hline Moderate Vegetation & 11905 & 13543 & 8576 & 4479 & 3990 & -62.38 & -10.92 \\
\hline Dense Vegetation & 8071 & 9292 & 17533 & 16341 & 11427 & +102.47 & -30.07 \\
\hline \multicolumn{8}{|l|}{ Nhilla Union } \\
\hline Sparse Vegetation & 7752 & 6256 & 3357 & 1915 & 4416 & -75.30 & +130.60 \\
\hline Moderate Vegetation & 2584 & 4147 & 6301 & 1928 & 1123 & -25.39 & -41.75 \\
\hline Dense Vegetation & 320 & 415 & 2008 & 1910 & 901 & +496.88 & -52.83 \\
\hline \multicolumn{8}{|l|}{ Baharchhara Union } \\
\hline Sparse Vegetation & 2206 & 1924 & 1220 & 690 & 1332 & -68.72 & +93.04 \\
\hline Moderate Vegetation & 670 & 1170 & 1464 & 827 & 387 & +23.43 & -53.20 \\
\hline Dense Vegetation & 107 & 41 & 665 & 655 & 805 & +512.15 & +22.90 \\
\hline
\end{tabular}

Note: ótôand óôsign indicates increasing and decreasing respectively

In all of the four Unions, the area of sparse vegetation in 2017 has been decreased in comparison with 1988, but they have again increased in 2018. Overall, noticeable reduction of dense vegetation is observed in Palong Khali, Whykong, and Nhilla Unions where maximum numbers of refugee settlements are established. All of the land covers mentioned in Table 4 are interlinked with each other. That means change in one type might have influenced the change of others. Even a particular type of vegetation cover can be converted into another one due to exploitation and/or plantation. The uneven change of the three vegetation covers over the four decades clearly reveals their interlinked characteristics.

As we have found that the forest cover of the selected refugee occupied Unions have been reduced evidently (Table 4), the area of refugee settlements has also been expanded accordingly. The changes of the area of refugee sites are shown in Table 5. The previously established two refugee camps, Palong Khali and Nhilla, are expanded by 3714 and 1305 acres respectively. On the other hand, the newly established sites, Whykong and Baharchhara, are expanded by 206 
and 662 acres respectively. Overall, the expansion of refugee settlements after 2017 Influx has consumed almost six thousand acres of land; most of those were previously occupied by vegetation cover.

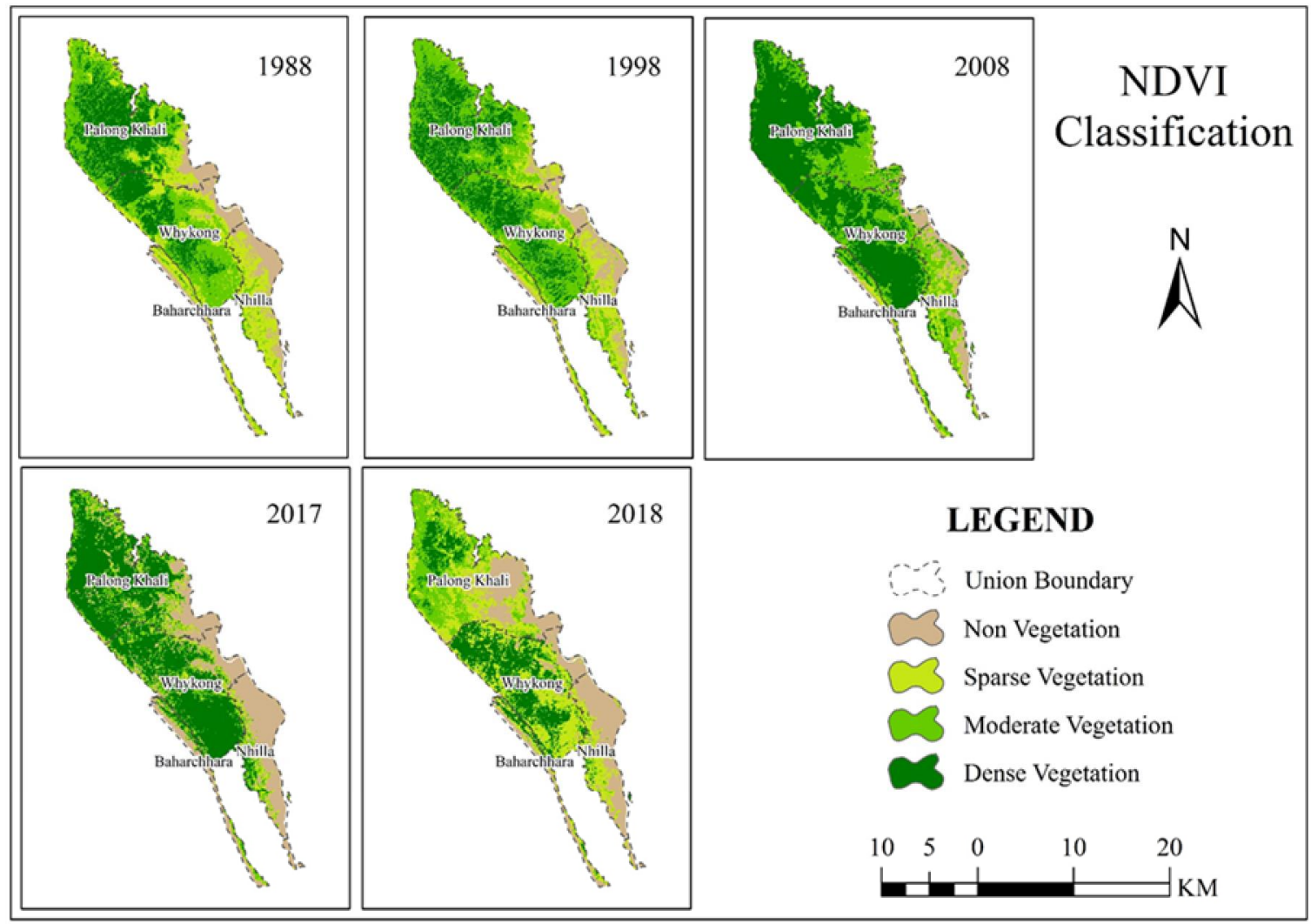

Fig. 2. Change of the extent of vegetation over the years

Table 5. Area of refugee settlements before and after 2017-Refugee-Influx

\begin{tabular}{ccccc}
\hline \multirow{2}{*}{ Union } & \multicolumn{3}{c}{ Area of Refugee Sites (Acre) } & Area Expanded (Acre) \\
\cline { 2 - 4 } & pre-Aug. 2017 & Dec. 2017 & May 2018** & (August'17 to May'18) \\
\hline Palong Khali & 361 & 3373 & 4075 & 3714 \\
Whykong & - & 79 & 206 & 206 \\
Nhilla & 72 & 329 & 1377 & 1305 \\
Baharchhara & - & - & 662 & 662 \\
\hline
\end{tabular}

*Hassan et al. (2018); ${ }^{* *}$ Collected from IOM 


\section{Discussion}

Coxôs Bazar and other surrounding districts of the south-eastern Bangladesh are rich in natural resources and biodiversity. The four Unions that have been studied in this paper were occupied by different types of vegetation since long before. It can be seen from Figure 2 that most of the landscape of the study area was covered by vegetation in 1988, where dense vegetation was mostly concentrated in Palong Khali. Over the next two decades (from 1988 to 2008) the extent of vegetation cover has increased significantly as the image of 2008 shows maximum concentration of vegetation across the study area. Within the next decade (from 2008 to 2017) vegetation cover has decreased along the Myanmar border. Consumption of woods by pre-settled refugees to meet their demand of cooking fuel might be a reason for this occurrence. In this circumstance, a sudden and rapid arrival of refugees started in August 2017 and the hosting administration was totally unprepared to accommodate them in a sustainable way causing least damage to the environment. Despite the potential risk of environmental degradation, hosting administration felt the necessity of giving them urgent refuge in order to save their lives as they fled a violent crackdown. Moreover, it was unclear at the beginning that how long they will stay in Bangladesh as the initiative was already taken to repatriate them to their homeland. As a result, instead of searching more suitable location with less ecological threat, the host administration has arranged their living place by expanding the previously established refugee camps as well as some new camps have also been established. For example, Whykong and Baharchhara Unions were not previously occupied by refugees (Table 5).

To accommodate the large number of refugees, a considerable amount of forest cover was chopped off. Figure 2 shows that a noticeable amount of nonvegetation land has increased in Palong Khali in the year of 2018 than previous years as well as the density of vegetation has also been decreased as the colour of vegetation turned into light green from deep green. Whykong and Nhilla Union have also showed the decrease of vegetation density in 2018 than the previous year. Degradation of vegetation has occurred in mainly two ways $ठ$ some portion of the forest land have been demolished to build refugee settlements and refugees are cutting down trees of the existing forests nearby their camps to collect household fuel. As a result, the findings of NDVI classification show the decreasing of dense vegetation and increasing of moderate and sparse vegetation in some Unions (Table $4)$. Due to the scattered chopping of trees in order to collect firewood, many portion of the dense vegetation might have been converted into moderate vegetation, especially in Palong Khali Union (Figure 2). This is why the area of moderate vegetation has increased despite the decreasing of dense vegetation in this Union. Therefore, increasing of moderate vegetation doesnô imply the increasing of vegetation, but indicate the decreasing of dense vegetation. On the other hand, the possible explanation of the increasing of sparse vegetation in almost all Union in 2018 might be that the image of 2018 was acquired during monsoon; hence, the appearance of grass, herbs, and straw-type vegetation was adequate. Nevertheless, the negative impact of Rohingya refugee influx on vegetation cover has firmly been established based on the findings of the study as altogether about 20,769 acres of dense vegetation have been reduced within just one year (inbetween 2017 and 2018) in the study area (Table 4). This huge amount of reduction of dense vegetation cannot be a normal phenomenon in any sense instead of a consequence of the severe impacts of rapid refugee inflow and settlement building. Such rapid degradation of forested land will trigger ecological problems and will disturb wildlife habitats in the area since many of these makeshift resettlement camps were set up in or near the corridors for wild elephants, which already caused several incidents of conflict between Rohingya and elephants (Hasan et al. 2018).

\section{Conclusion}

The main goal of the study was to investigate the change in vegetation covers in refugee occupied areas of Coxôs Bazar in-between the period of pre and post 2017 Influx in comparison with the changes of previous decades in order to assess the impact of rapid refugee arrival and site expansion. The findings of the NDVI classification conclude that nearly 21 thousand acres of dense vegetation have reduced within the period of one year in-between 2017 and 2018 in Palong Khali, Whykong, and Nhilla Union, while more than 17 hundred acres of moderate vegetation have reduced in Whykong, Nhilla, and Baharchhara Union within the same period. Reduction of such a huge amount of vegetation cover within just one year is an unusual occurrence, which implies that the impact of refugee influx and expansion of the refugee camps on vegetation cover is very severe. However, the refugee influx was an unavoidable humanitarian crisis. During an emergency when human lives are in a vulnerable condition, it is quite difficult to maintain environmental sustainability rather paying attention to address the immediate humanitarian crisis. As a result, degradation of the environment due to refugee influx can be called collateral damage which is very normal 
and inevitable. Despite this fact, some measures have to be taken to mitigate the further loss. Until repatriation, the refuges can be relocated in less ecological vulnerable areas. Since Bangladesh is an overpopulated country, relocation might be a difficult task. Therefore, some interim measures can be taken. They are: arrangement of alternative cooking facilities based on gas cylinder to reduce the consumption of firewood, and a massive reforestation program with participation of local, national, and international development partners in order to mitigate the loss of rapid deforestation. Above all, repatriation of the refugees to their homeland needs to be initiated as early as possible with mutual cooperation of all stakeholders to reduce the pressure on the host environment.

Every study opens the doors for further study. Since vegetation is the only one environmental element of many, and other elements, i.e. wildlife, soil, water has also possibility of being damaged by this crisis; further study can be initiated to examine the degradation of other environmental variables. Only then a comprehensive scenario of environmental degradation due to refugee influx will be found.

\section{Acknowledgements}

The authors are thankful to Md. Nazir Hossain, Assistant Commissioner, Office of the Deputy Commissioner, Kishoreganj for his valuable comments on the manuscript.

\section{References}

Barun, A., Lang, S., Hochschild, V. 2016. Impact of Refugee Camps on Their Environment: A Case Study Using Multi-Temporal SAR Data. Journal of Geography, Environment and Earth Science International, 4(2), 1-17, DOI: 10.9734/JGEESI/2016/22392

Gomez, M. P., Christensen, A., Araya, Y. Y., Harild, N. 2010. The impacts of refugees on neighboring countries: a development challenge (English). World Development Report background papers; 2011. Washington, DC: World Bank.

Hassan, M. M., Smith, C.A., Walker, K., Rahman, M.K., Southworth, J. 2018. Rohingya Refugee Crisis and Forest Cover Change in Teknaf, Bangladesh. Remote Sensing, 10: 689, DOI:10.3390/rs10050689

Human Right Watch (HRW). 2017. Massacre by the river: Burmese Army Crimes against Humanity in Tula Toli. Washington, DC: Human Rights Watch. https://www.hrw.org/sites/default/files/report_ pdf/burma1217_web.pdf

Iftekhar, M.S., Hoque, A.K.F. 2005. Causes of forest encroachment: An analysis in Bangladesh. GeoJournal, 62, 95-106

Imtiaz, S. 2018. Ecological impact of Rohingya refugees on forest resources: remote sensing analysis of vegetation cover change in Teknaf Peninsula in Bangladesh. Ecocycles, 4(1), 1619, DOI: 10.19040/ecocycles.v4i1.89

Inter Sector Coordination Group (ISCG). 2018. Situation Report Rohingya Refugee Crisis. https://reliefweb.int/sites/reliefweb.int/files/re sources/iscg_situation_report_29_nov.pdf (Accessed on January 06, 2019)

Inter Sector Coordination Group (ISCG). 2018. Situation Report: Rohingya Refuge Crisis. https://reliefweb.int/sites/reliefweb.int/files/re sources/180225_weeklyiscg_sitrep_final.pdf (Accessed on September 22, 2018).

Leider, J. 2018. Rohingya: The History of a Muslim Identity in Myanmar. Oxford Research Encyclopedia of Asian History. DOI: 10.1093/acrefore/9780190277727.013.115

Martin, A. 2015. Environmental conflicts between refugee and host communities. Journal of Peace Research, 42(3), 329-346, DOI $10.1177 / 0022343305052015$

Médecins Sans Frontières-Holland (MSF). 2002. 10 Years for Rohingya Refugees in Bangladesh: Past, Present and Future. http://www.rnapress.com/data/itemfiles/5ae98e43d068cb749 b3060b002601b95.pdf (Accessed on January 12, 2019)

Muller, F. M., Yoon., J., Gorelick., S. M., Avisse., N., Tilment., A. 2016. Impact of the Syrian refugee crisis on land use and trans boundary freshwater resources. Proc Natl Acad Sci U S A, 113(52), 14932-14937, DOI: 10.1073/pnas. 1614342113

Nath, B. 2015. NDVI ï An Indicator of Forest Cover Change Detection: A Geospatial Study on Chunati Forest Beat Areas, Chittagong, Bangladesh. Journal of Image Processing \& Pattern Recognition Progress, 2(1), 5-18

Rahman, L. M. 2016. Bangladesh National Conservation Strategy: Forest Resources. Dhaka: Department of Forest and International Union for Conservation of Nature.http://bforest.portal.gov.bd/sites/defaul t/files/files/bforest.portal.gov.bd/notices/c337 9d22_ee62_4dec_9e29_75171074d885/4.\%20 Forest\%20resources_NCS.pdf (Accessed on September 29, 2018) 
Shepherd, G. 1995. The Impact of Refugees on the Environment and Appropriate Responses. https://odihpn.org/magazine/the-impact-ofrefugees-on-the-environment-andappropriate-responses [Accessed on September 22, 2018]

United Nations High Commissioner for Refugees (UNHCR). 2011. UNHCR Resettlement Handbook. Geneva: United Nations High Commissioner for Refugees, pp. 19

United Nations High Commissioner for Refugees (UNHCR). 2018a. Global Trends 2017. Geneva: United Nations High Commissioner for Refugees, pp. 2
United Nations High Commissioner for Refugees (UNHCR). 2018b. Global Trends 2017. Geneva: United Nations High Commissioner for Refugees, pp. 3

United Nations Office for the Coordination of Humanitarian Affairs (UNOCHA). (n.d.). Rohingya Refugee Crisis (RRC). https://www.unocha.org/rohingya-refugeecrisis (Accessed on September 22, 2018).

Weier, J., Herring, D. 2000. Measuring vegetation (NDVI \& EVI). NASA Earth Observatory, Washington DC. https://earthobservatory.nasa.gov/Features/Me asuringVegetation (Accessed on September 22, 2018) 